\title{
Agricultural Extension for Enhancing Production and Productivity: The Case of Southern Ethiopia, Arba Minch Zuriya District
}

\author{
Molla Mekonnen Alemu \\ De Montfort University, Leicester, England \\ Email: mollamekonnen@gmail.com
}

How to cite this paper: Alemu, M.M (2017) Agricultural Extension for Enhancing Production and Productivity: The Case of Southern Ethiopia, Arba Minch Zuriya District. Open Access Library Journal, 4: e3427.

https://doi.org/10.4236/oalib.1103427

Received: February 4, 2017

Accepted: April 22, 2017

Published: April 25, 2017

Copyright (c) 2017 by author and Open Access Library Inc.

This work is licensed under the Creative Commons Attribution International License (CC BY 4.0).

http://creativecommons.org/licenses/by/4.0/

\begin{abstract}
Agricultural production systems are believed to evolve through different developmental stages that shaped up its current state. Literatures mentioned that the latest agricultural development seems to have been in Southwest Asia, mainly in the present day Turkey and Iraq area. Agricultural extension efforts in Ethiopia have helped the transformation of productivity and production. It has contributed for reduction of poverty and for the development of the economic and human capitals of the country. This study was conducted to assess the major strengths and limitations of agricultural extension activities in the southern Ethiopia with a major focus on Arba Minch Zuriya district. The study was carried out by involving 78 agricultural communities of the area and 12 representatives of the concerned governmental institutions. The findings of the study have showed as the agricultural extension system in the area is playing a pivotal role in terms of food security, local and regional economic development and the creation of employment opportunities. However, the agricultural extension efforts are also being challenged by the producer's level of awareness, shortage of rainfall and increased cost of agricultural inputs. Therefore, enhancing the traditional and modern irrigation practices, improved market linkages, creation of the enabling environment to better organize cooperatives and associations could help to increase the significantly impacting agricultural services of the region in particular and the country in general.
\end{abstract}

\section{Subject Areas}

Natural Geography

\section{Keywords}

Agriculture, Extension, Food Security, Production 


\section{Introduction}

The historical development of agriculture is the history of mankind since it is closely related with the ever improving and increasing development for the demand on food, feed, energy and other goods and services that originates from plants and animals. Before the emergence of crop production, humans were sustaining their life by hunting and gathering edible items from the wild. It is believed that the development of the humans was enhanced as a result of the increased know-how on caring for soil the growth of plants. This phenomenon has also created the condition for people to stay in one specific location than moving from area to the other in search of food. Archeologists indicated as this change started to happen around 10,000 years ago. This agricultural development has helped the development of clans, societies and regions as a result of the trade and relationship that developed among humans. The traditional way of hunting and gathering lifestyles were taken away by permanent settlements with a steady food supply. In that vein agriculture has caused the emergence of cities and civilization. Thus, agriculture has played a leading role for centuries in bringing people to a more developed system and era [1].

The wild predecessors of the modern day crop production system include wheat, barley and peas are traced from the Near East. There are anthropological and archaeological evidences that show the use of wild cereals along the Nile basin during the 10th millennium B.C.E. In Syria cereals were cultivated about 9000 years ago. The discovery of seedless fruits in the Jordanian Valley also indicated that, fit trees have been cultivated in the area around 11,300 years ago. The production of rice and millets also dates back to the Neolithic time in China. It is also believed that, squashes were cultivated in Mexico around 10,000 years. It is also believed as the domestication of cattle, goats, pigs and sheep was started in the so-called Fertile Crescent (the area that covers eastern Turkey, Iraq and southwestern Iran) about 10,000 - 13,000 years ago. Genetic research also shows that goats and other livestock productions have helped the westward spread of agriculture to Europe [2].

Agriculture has led for the establishment of metropolitan area and allowed farmers to specialize on the provision of food items which enabled others to focus on art, construction, governance, etc. Agriculture provided the springboard towards revolution, democracy, trade and religion. Literature also mentioned that, one of the reasons why many religions worshiped the sun was since people noticed as the sun provided light for the growth of plants [3].

Population growth, however, in various parts of the world has led for the increased dependence on improving agricultural production and productivity. World's population has reached 7.3 billion in 2015, 6.9 billion in 2010, up from 2.5 billion in 1950 and 3.7 billion in 1970 [4]. The UN also projected as the total world population will reach 9.15 billion in 2050. Many of the developing countries are still struggling to feed their people as a result of the increased competition for the available natural resources coupled with poverty and the devastating 
effects of climate change. Hence, the development of agricultural extension programmes is taken as a tool to increase production and productivity of the sector [5].

The concept of agricultural extension goes back to 1840 where the term "extension" was first coined with the University education in order to explain methods of spreading skills and knowledge to the wider community. The term was often called as "University Extension" and incorporated into proposals arising from the Royal Commission on the University and Colleges of Oxford (1852) largely arising from the evidence submitted by William Swell in suggestions for the extension of the University (1850). The initial practical actions were taken by James Stuart, who is often considered as "the father of university extension" as he gave the first lectures to women's associations and working men's clubs in northern England. At latter stages the concept of agricultural extension has evolved through the intension of extending knowledge for the people to be served who doesn't have the chance of getting the formal education. Agricultural extension henceforth played to transform the lives of many by increasing agricultural production, productivity, enhancing food security and increasing income and employment opportunities [6].

\section{Agricultural Extension in Ethiopia}

There is ample evidence as agriculture has been practiced in the Nile basin during the 10th millennium B.C.E. [2] indicating as agricultural activities are a centuries old practice in Ethiopia. There were sort of "extension type" activities going on in the country (1890-99) mainly in the areas of Eucalyptus development, irrigation and improved agricultural production practices. The recent development dates back to 1908 when the then "yeirsha Mesriabet" (Office of Agriculture) was officially organized by proclamation. This Ministry was established with the overall role of giving advisory service on and monitoring of both crop and livestock production; animal health service; forestry development and conservation and collecting agricultural statistics. These objectives were established with the agreement that individuals who violate the proclamation to be punished while those who adhere to its regulations would be rewarded.

In the year 1931 the then "Yeirhsa Mesriabet" was restructured through a proclamation, and named as the Ministry of Agriculture. Since 1943 and thereof, however, there have been organized and concerted endeavors made to increase agricultural production in different parts of the country. A number of demonstration sites were established throughout the country. The Sholla Poultry Demonstration Center, Andasa (Gojam) and Adami Tullu (Shewa) ranches, and the Intoto, Kundi, Kofele, Bale, Jijiga and Amed Guya sheep ranches for mutton production were among to be mentioned [7].

Ethiopia is an agrarian country whose economy is dependent on agriculture. Agriculture is the main stay of livelihoods for about $85 \%$ of the country's population. The sector also accounts $43 \%$ of the GDP and $90 \%$ of exports [8]. Ethi- 
opia's agriculture is heavily dependent on natural rainfall, with irrigated land accounting for less than 1 per cent of the total cultivated land [9].

Ethiopia has exhibited a strong track record of economic development by achieving a double digit economic growth for consecutive years. The country was able to achieve this development as a result of the $15 \%$ expansion of agricultural land and the $40 \%$ yield increase of the agriculture sector for consecutive years. Coffee, sesame, leather, flowers and gold are the major export goods of the country. The country is also the 10th largest producer of livestock in the world [10].

The agricultural development efforts, however, are still being challenged by low levels of market linkages, low levels in the use of agricultural inputs, environmental degradation and the effects of climate change and global warming.

\section{Methodology}

\subsection{Country Context}

The country is located in the North East Africa region, the Horn of Africa, approximately $32^{\circ} 58^{\prime} 00^{\prime \prime} \mathrm{E}$ to $48^{\circ} 00^{\prime} 00^{\prime \prime} \mathrm{E}$ and $14^{\circ} 55^{\prime} 00^{\prime \prime} \mathrm{N}$ to $3^{\circ} 25^{\prime} 00^{\prime \prime} \mathrm{N}$. It is bordered by Eritrea to the north, Djibouti and Somalia to the east, Sudan and South Sudan to the west, and Kenya to the south. It occupies a total area of 1,104,300 $\mathrm{km}^{2}$ and is a landlocked country. Ethiopia has a tremendous diversity of climatic and biophysical settings, ranging from equatorial rainforest in the south and southwest characterized by high rainfall and humidity, to Afro-Alpine on the summits of the Semen and Bale mountains and desert-like ecologies in the north-east, east and south-east lowlands. The altitude ranges from 126 meters below sea level at the Kobar sink in the Dallol Depression to 4620 meters above sea level at Ras Dashen in the Semien Mountains where temperatures are below freezing point for the major portion of the year. Annual rainfall varies from 3000 $\mathrm{mm}$ at the Masha area in the Baro-Akobo Basin to barely $200 \mathrm{~mm}$ along the Ethio-Djibouti and Ethio-Somali border areas of the Ogaden and Aysha basins [9].

\subsection{Description of the Study Area}

Arba Minch Zuriya district is located in the Gamo Gofa zone of the Southern Nations and Nationalities Peoples' Regional State of the Federal Democratic Republic of Ethiopia. The district is located about $505 \mathrm{~km}$ south west of Addis Ababa and has a total of 29 Kebeles (the smallest administration unit in the country). Agro ecologically 4 kebeles are highlands, 15 kebeles at mid altitude and the rest 10 are found in the low land zone. The district has a total population of 74,879 in Arba Minch city and 164,529 in Arba Minch Zuriya district. The altitude of the district ranges from 1200 - 3300 masl with a rainfall amount of 800 $\mathrm{mm}-1200 \mathrm{~mm}$ per annum. The temperature also ranges from $16^{\circ} \mathrm{C}-37^{\circ} \mathrm{C}$. There are two cropping seasons, namely, Belg (short rainy season), Meher (main rainy season). The short rainy season starts from March to May while the main 
rainy season is from Jun to September. The district is also surrounded by the two Rift Valley lakes namely Chamo and Abaya that have a great economic as well as ecological value to the area [11] (Table 1, Figure 1).

\subsection{Data Collection and Analysis}

Primary data were collected from the locality by making use of focus group discussions and semi structured interviews from June-July, 2016. The participants (local community members) were selected through systematic sampling from the kebeles (the smallest administration units) of the district. Government officials were also interviewed. Different reports and literatures were also reviewed. 78 (24 female) households and 12 government officials were considered for the primary data collection. The primary information collected through focus group discussion, interview and observation was separately transcribed which helped

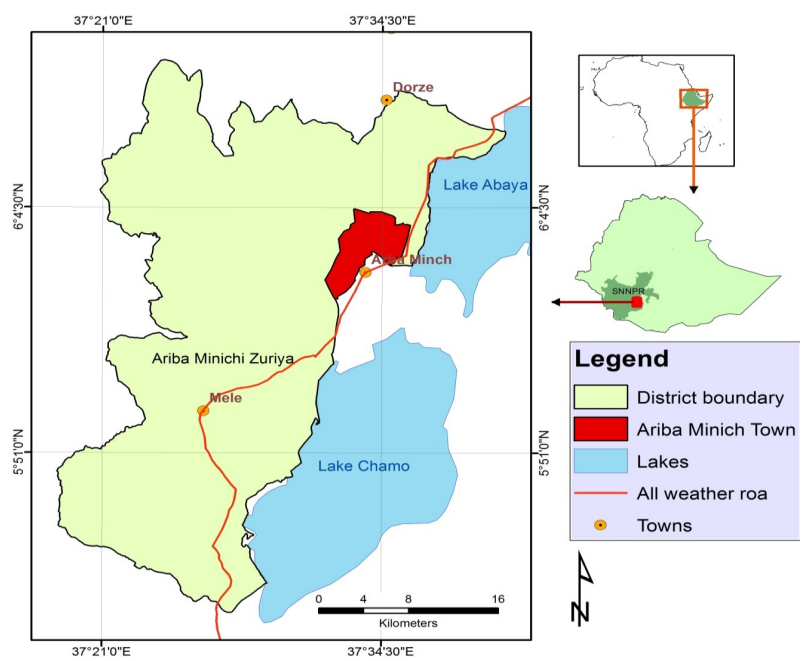

Figure 1. Location map of Arba Minch Zuriya district.

Table 1. Land use patterns of Arba Minch district [12].

\begin{tabular}{ccc}
\hline S.N & Land-use Type & Area (hectare) \\
\hline 1 & Arable land & 11,779 \\
2 & Farm land & 34,137 \\
3 & Land covered with annual crops & 16,183 \\
4 & Land covered with perennials & 17,954 \\
5 & Bush land & 4981 \\
6 & Forest & 5088 \\
7 & Grazing land & 2,767 \\
8 & Wetland & 946 \\
9 & Marginal land & 2714 \\
10 & Land covered by water bodies & 84,365 \\
11 & others & 23,320 \\
\hline
\end{tabular}


the raw data to be ready for scientific analysis. Then content analysis of the information was made and main points were analyzed [13] [14].

\section{Results and Discussion}

Wheat, Barley, Maize, Haricot been, Teff and Sweet potatoes are the major crops of the Arba Minch Zuriya district which in most cases are produced by rain-fed agriculture and supplementary irrigation systems (Figure 2). Agricultural extension activities in the form of technical assistance and provision of improved inputs such as improved seeds, fertilizers, and water harvesting technologies, etc. are hugely contributing for the realization of food security in the area by maximizing the productivity and production potentials of the region's natural capital.

Water harvesting technologies like motorized water pump (Robben pump) and Tridle pumps are being used so as to increase the irrigation water use efficiency. Rain water harvesting activities are also practiced by making use of geomembranes. According to the respondents, the extension services have helped them to maximize agricultural production and enhance their food security at household level. According to the respondents, the community can now afford nutritious foods like eggs, milk, etc. very easily as compared to earlier years (Figure 3). One elder have also mentioned "now my former medical expenses are being used to buy better clothing items for my family". Many have also mentioned as they are able to send their children to school since they can afford to hire labor for the farm related activities and hence as been depicted in Table 2 school enrollment rates have also showed a tremendous change across time. The 2017 school enrolment rate of the district has also reached 91\% [15].

According to official reports of the Office of Agriculture (Table 3) the agricultural production capacity of the district has increased considerably. This has contributed a lot for the local economic development along with employment opportunities for the rural and urban youth. Different rivers and their tributaries are also being used as sources of irrigation water in the district (Table 4) and have contributed a lot for the maximization of yield in the area.

The increasing erratic nature of rainfall, land resources degradation, and im-
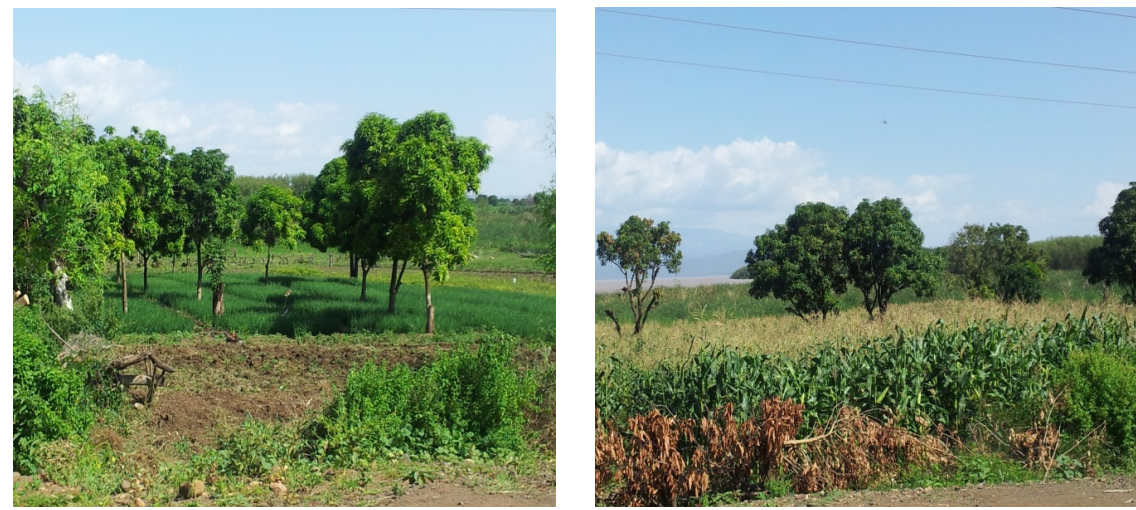

Figure 2. Improved agroforestry based agricultural practices (Lante Kebel). 


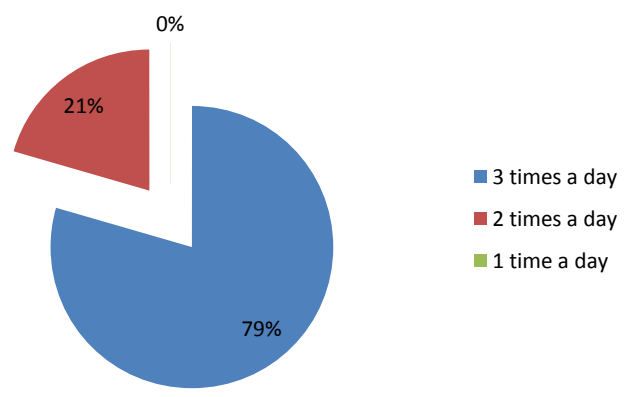

Figure 3. Response analysis on the number of meals per day.

Table 2. School enrolment rate of Arba Minch Zuriya district [15].

\begin{tabular}{cccc}
\hline S.N. & Academic Year & $\begin{array}{c}\text { Total number of enrolled } \\
\text { students }\end{array}$ & $\begin{array}{c}\text { \% change from the } \\
\text { previous year }\end{array}$ \\
\hline 1 & $2016 / 2017$ & 48,049 & $>5.98$ \\
2 & $2015 / 2016$ & 45,335 & $>13.9$ \\
3 & $2014 / 2015$ & 39,799 & $>1.03$ \\
4 & $2013 / 2014$ & 39,393 & $>9.07$ \\
5 & $2012 / 2013$ & 36,115 & $>1.0$ \\
6 & $2011 / 2012$ & 35,862 & $<4.16$ \\
7 & $2010 / 2011$ & 37,419 & $>19.2$ \\
8 & $2009 / 2010$ & 31384 & $>7.8$ \\
9 & $2008 / 2009$ & 29,107 & \\
\hline
\end{tabular}

NB: > denotes increase, $<$ denotes decrease.

Table 3. Productivity trend of the major crops in Arba Minch Zuriya district [12].

\begin{tabular}{lcccccc}
\hline \multirow{2}{*}{ S.N } & Crop Type & \multicolumn{5}{c}{ Year (Yield (quintal)/hectare) } \\
\cline { 3 - 7 } & 2012 & 2013 & 2014 & 2015 & 2016 \\
\hline 1 & Maize & 76 & 58 & 48 & 48 & 38 \\
2 & Teff & 8 & 10 & 12 & 16 & 16 \\
3 & Wheat & 35 & - & 42 & - & 45 \\
4 & Barley & 24 & - & - & - & 30 \\
5 & Kidney beans & 20 & 22 & 26 & 30 & 32 \\
6 & Banana & 300 & 300 & 300 & 300 & 300 \\
7 & Mango & 200 & 200 & 200 & 200 & 200 \\
\hline
\end{tabular}

proper use of irrigation water are among the agronomic factors which affect the potential productivity of the areas land resources. The increasing cost of agricultural inputs is also a challenge affects the profit margins of the production at the household level. Improper land-use practices such as farming on hilly slopes, low level of soil and water conservation activities are also observed on the farm fields. These activities will have a short and longer term effect on the productivity of the land resources and the environment (Figure 4). 
Table 4. Arba Minch Zuriya district major rivers used for irrigation [16].

\begin{tabular}{|c|c|c|c|}
\hline S.N & $\begin{array}{l}\text { Name of } \\
\text { River }\end{array}$ & $\begin{array}{l}\text { Kebeles/localities } \\
\text { covered by the river }\end{array}$ & Remark \\
\hline 1 & Baso & Ocholo-Lante and Omo-Lante & All use traditional diversion dam \\
\hline 2 & Dehe & Ocholo-Lante and Omo-Lante & $\begin{array}{c}\text { Use modern diversion dam constructed by } \\
\text { Vita (EU financed NGO) }\end{array}$ \\
\hline 3 & Hare & $\begin{array}{l}\text { Kolla-Shara, Chano-Mille, } \\
\text { Chano-Dorga and Chano-Chelba }\end{array}$ & All use traditional diversion dam \\
\hline 4 & Sile & $\begin{array}{l}\text { Kanchama, Kolla-Shele } \\
\text { and Shele-Mella }\end{array}$ & $\begin{array}{l}\text { Lucy private farm also uses Sile river-by } \\
\text { pumping. Farmers use traditional diversion }\end{array}$ \\
\hline 5 & Sego & $\begin{array}{l}\text { Zeyise-Aelgo, Kolla-Shelle, and } \\
\text { Shelle-Mella (also Lucy private } \\
\text { farm) }\end{array}$ & $\begin{array}{l}\text { Lucy private farm also uses Sego river-by } \\
\text { pumping. Farmers use traditional diversion }\end{array}$ \\
\hline 6 & $\begin{array}{l}\text { Argoba or } \\
\text { Wezeka }\end{array}$ & Zeyise, Wezeka & All use traditional diversion dam \\
\hline 7 & Waso & Ocholo-Lante & All use traditional diversion dam \\
\hline 8 & Kulfo & $\begin{array}{l}\text { Private investors (Omotic farm, } \\
\text { Kayiro farm, Amibara farm, } \\
\text { Mulat Hailu farm, Mirabu } \\
\text { Girma farm, etc. }\end{array}$ & $\begin{array}{l}\text { All use through the modern diversion dam } \\
\text { constructed by Amibara private farm. } \\
\text { Farmers also grow some vegetables and other } \\
\text { fruits (papaya \& mango). Amira farm also } \\
\text { grows cotton and maize under irrigation }\end{array}$ \\
\hline
\end{tabular}
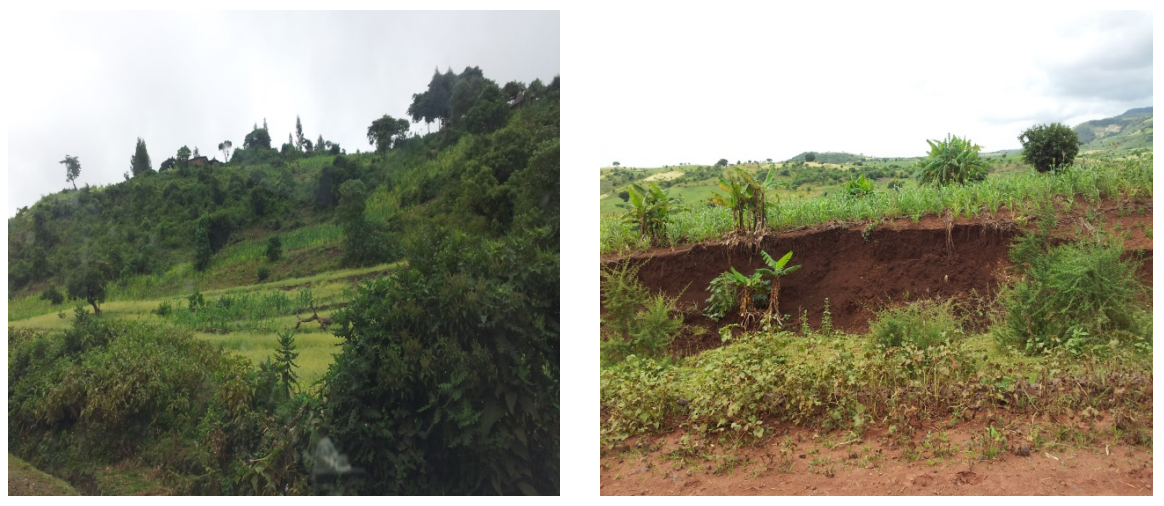

Figure 4. Improper land-use practices (left-hillside farming and right-gully formation).

Periodic skills development training programmes are organized for the beneficiary farmers. For the diffusion of agricultural extension programmes the grass-roots level development agents also uses on-farm demonstration sites and field days as the practical approaches and this is resulting to have an increased level of adoption as it has empowered the producers economically.

Traditional storage facilities like "Gotera" made of bamboo and sometimes mud are used to store maize, wheat, barley and teff. "Kote" is also used to store potato. Rats, rodents and other storage pests namely weevil are having negative impacts on the quality and quantity of produces since the traditional storage facilities are not designed to control the effects of these storage pests. On average the produce will be in these facilities 3 - 4 months of time. Although some NGOs are working to improve the post-harvest losses caused by storage facilities, ground truthing have indicated as a lot of need to be done to transform the storage facilities in each and every household (Figure 5).

The traditional and improper post-harvest handling activities during thrash- 


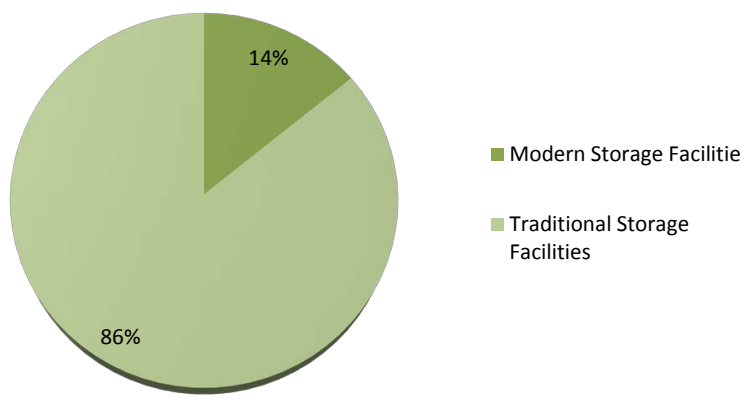

Figure 5. Proportion storage facilities being used in the district.

ing, purifying and transportation are also contributing for the loss in the amount and quality of products. The transport of perishable fruits and vegetables like banana and tomato doesn't also involve the use of boxes so as to avoid the physical damage on the fruits and lower the income to be generated and quality of the produce. Donkeys are the essential pack animals in the areas since they are the one used to transport most of the produce from the farm fields to the storage facilities.

In order to avoid conducive conditions for pest infestation in the storage facilities, farmers usually will expose the produce in to the sun and wind so that the moisture content can get down before it is stored. In order to monitor pest infestation, the storage facilities will also be monitored and checked on regular basis.

\section{Conclusion}

Ethiopia, the "the water tower of East Africa" is endowed with immense natural resources which be tapped to enhance agricultural production and productivity. The country also has varied agroecology which accommodate the production of different cereals, fruit, vegetables, timber and livestock products. These potential resources, however, are under-utilized as a result of low level of awareness, low level of irrigation development, weak research and extension linkage, land degradation and some other natural and anthropogenic factors. However, increase awareness development, irrigation development, strengthening of the country's agricultural cooperatives and associations, development and strengthening of agricultural value chins and capacitating the grassroots level development agents will have a tremendous impact on the country's effort of being a middle income country by the year 2025 .

\section{References}

[1] NEW (New World Encyclopedia) (2015) History of Agriculture. http://www.newworldencyclopedia.org/entry/History_of_agriculture

[2] NG (National Geographic) (2016) The Development of Agriculture. https://genographic.nationalgeographic.com/development-of-agriculture/

[3] Flannigan, W. (2012) What Is Agriculture and Where Did It Begin? The Social Silo. http://www.thesocialsilo.com/2012/07/24/what-is-agriculture-and-where-did-it-beg in/ 
[4] PRB (Population Reference Bureau) (2016) 2015 World Population Data Sheet. Washington DC.

[5] Alexandratos, N. and Bruinsma, J. (2012) World Agriculture towards 2030/2050: The 2012 Revision. ESA Working Paper No. 12-03, FAO, Rome.

[6] AU (Alamaya University) (1999) Concepts of Agricultural Extension. Faculty of Agriculture, Department of Agricultural Extension, Alamaya University, Ethiopia.

[7] AU (Alamaya University) (2000) History of Agricultural Extension in Ethiopia. Faculty of Agriculture, Department of Agricultural Extension, Alamaya University, Ethiopia.

[8] USAID (2016) Agriculture and Food Security in Ethiopia. Addis Ababa, Ethiopia.

[9] MEF (Ministry of Environment and Forest) (2015) Ethiopia's Second National Communication to the United Nations Framework Convention on Climate Change (UNFCCC). Addis Ababa, Ethiopia.

[10] ECRGE (Ethiopia's Climate-Resilient Green Economy) (2011) Federal Democratic Republic of Ethiopia, Green Economy Strategy. Addis Ababa, Ethiopia.

[11] FDRE-PCC (Federal Democratic Republic of Ethiopia, Population Census Commission) (2008) Summary and Statistical Report of the 2007 Population and Housing Census. Addis Ababa, Ethiopia.

[12] Arba Minch Zuriya District Office of Agriculture (2017) Annual Report on the Productivity of the Major Crops in the District. Arba Minch, Ethiopia.

[13] Hennie, B. (2010) Analysis in Qualitative Research. SAGE, Los Angeles.

[14] Flick, U., Kardorff, E. and Steinke, I. (2004) A Companion to Qualitative Research. Sage Publications, London.

[15] Arba Minch Zuriya District Office of Education (2017) School Enrolment Rate of the District. Arba Minch, Ethiopia.

[16] Woldu, Z., Mohammed, A., Belew, D., Shumeta, Z. and Bekele, A. (2015) Assessment of Banana Production and Marketing in Ethiopia. International Journal of Sciences. Basic and Applied Research (IJSBAR), 24, 283-307.

Submit or recommend next manuscript to OALib Journal and we will provide best service for you:

- Publication frequency: Monthly

- 9 subject areas of science, technology and medicine

- Fair and rigorous peer-review system

- Fast publication process

- Article promotion in various social networking sites (LinkedIn, Facebook, Twitter, etc.)

- Maximum dissemination of your research work

Submit Your Paper Online: Click Here to Submit

Or Contact service@oalib.com 